\title{
KAJIAN FILOSOFIS TENTANG KONSEP KEADILAN DARI PEMIKIRAN KLASIK SAMPAI PEMIKIRAN MODERN
}

\author{
Bahder Johan Nasution \\ Fakultas Hukum Universitas Jambi
}

\begin{abstract}
Justice, since the first issue, has been the subject of study both among philosophers and among theologians, politicians and thinkers or legal experts. However, if there are questions about justice, could not be determined what measures are used to determine something is fair or not. Various answers about justice usually never or rarely satisfying so that continues to be debated, so it can be concluded that the various formulations of justice is a relative statement. This issue ultimately encourages many people to take a shortcut by submitting formulation of justice to the legislators and judges who will formulate it based on their own considerations.
\end{abstract}

Keywords : Philosophy, justice

\begin{abstract}
Abstrak
Masalah keadilan sejak dahulu telah menjadi bahan kajian baik dikalangan ahli filsafat maupun dikalangan agamawan, politikus maupun para pemikir atau ahli hukum. Pertanyaan tetang keadilan, tidak bisa ditentukan ukuran yang digunakan untuk menentukan sesuatu itu adil atau tidak. Berbagai jawaban tentang keadilan biasanya tidak pernah atau jarang yang memuaskan sehingga terus menjadi perdebatan, dengan demikian rumusan mengenai keadilan merupakan rumusan yang relatif. Persoalan ini pada akhirnya mendorong banyak kalangan untuk mengambil jalan pintas dengan menyerahkan perumusan keadilan kepada pembentuk undang-undang dan hakim yang akan merumuskannya berdasarkan pertimbangan mereka sendiri.
\end{abstract}

Keywords: Kajian Filosofis, Konsep Keadilan

\section{A. Pendahuluan}

Pemahaman terhadap konsep keadilan harus diterjemahkan dalam hubungannya dengan Pancasila, kemudian baru dikaitkan dengan kepentingan bangsa Indonesia sebagai bangsa yang harus merasakan keadilan itu. Dalam kaitannya dengan pengaturan hukum menurut konsep keadilan Pancasila, pengaturan tersebut dilakukan melalui pengaturan hukum yang sifatnya mengayomi bangsa, yakni melindungi manusia secara pasif (negatif) dengan mencegah tindakan sewenang-wenang, dan secara aktif (positif) dengan menciptakan kondisi kemasyarakatan yang manusiawi dan memungkinkan proses kemasyarakatan berlangsung secara wajar, sehingga secara adil tiap manusia memperoleh kesempatan yang luas untuk mengembangkan seluruh potensi kemanusiaannya secara utuh. Pengayoman dalam hal ini berarti rasa keadilan yang ada pada nurani manusia Indonesia harus terpenuhi. Dalam pengertian yang demikian ini konsep keadilan menurut pandangan bangsa Indonesia diartikan sebagai suatu kebajikan atau kebenaran.
Pengertian yang demikian ini bertolak pada pandangan tentang konsep keadilan yang didasarkan pada sila Ketuhanan Yang Maha Esa dengan sila Kemanusiaanya yang adil dan beradab. Sila Ketuhanan Yang Maha Esa menjadi dasar yang memimpin cita-cita negara, yang memberikan jiwa kepada usaha menyelenggarakan segala yang benar, adil dan baik, sedangkan sila Kemanusiaan yang adil dan beradab adalah kelanjutan perbuatan dan pratik hidup dari dasar yang memimpin tadi. Dasar Kemanusiaan yang adil dan beradab harus menyusul, berangkaian dengan dasar yang pertama. Letaknya tidak dapat dipisah sebab dia harus dipandang sebagai kelanjutan ke dalam praktek hidup dari cita-cita dan amal terhadap Tuhan Yang Maha Esa. Konsep keadilan ini tidak saja menjadi dasar hukum dari kehidupan bangsa, tetapi sekaligus menjadi pedoman pelaksanaan dan tujuan yang akan dicapai dengan hukum. Keadilan sosial adalah langkah yang menentukan untuk mencapai Indonesia yang adil dan makmur.

Immanuel Kant mengungkapkan bahwa keadilan yang tertinggi adalah ketidakadilan yang 
paling besar. Dengan kata lain keadilan yang bersifat absolut adalah manifestasi dari wujud ketidakadilan. Dalam tatanan yang tidak terlalu dogmatis, yang antara lain mendalilkan bahwa polisi lalu lintas adalah hukum, karena kesemuanya itu kita taati, maka kita pun menemukan pengertian keadilan dari pengertian hukum tersebut (Padmo Wahyono, 1992 : 129). Hal ini tidak jauh berbeda pada pemahaman yang berlaku pada sistem hukum common law, yang mana terdapat suatu paradigma pemahaman hukum oleh man on the street. Adapun pemahaman yang dimaksud itu adalah terdapat suatu pemikiran bahwa hukum adalah pengadilan, jaksa, hakim, polisi, dan perangkat hukum lainnya, yang berbentuk konkrit. Lebih lanjut Padmo Wahyono menyatakan bahwa keadilan adalah masalah hidup dalam kaitannya dengan orang lain atau masalah hidup berkelompok (Padmo Wahyono, 1992 130). Di samping itu pembahasan tentang keadilan, harus dikaitkan dengan kehidupan yang nyata, yang dikhususkan dalam hal ini keadilan dari segi pengertian hukum, dengan hukum positif negara kesatuan Republik Indonesia. Dimana ditambahkan bahwa mengaitkan masalah keadilan dengan arti hukum, yaitu dengan bersumber pada Undang-Undang Dasar Negara Republik Indonesia Tahun1945, berarti keadilan harus terkait pada dua hal di dalam kehidupan berkelompok di Indonesia yaitu; Keadilan terkait dengan ketertiban bernegara dan keadilan terkait dengan kesejahteraan sosial.

Dari dua aspek peranan hukum sebagai alat dapat diperoleh gambaran tentang keadilan yang harus ditumbuhkan, oleh karenanya terhadap produk-produk hukum yang dihasilkan, tidak jarang terjadi perdebatan tentang apakah perangkat peraturan hukum tersebut, telah dibentuk dengan tolok ukur tertentu, dimana dengan menggunakan parameter tersebut dapat diidentifikasi, bahwa sebuah perangkat hukum yang terbentuk bukan sekedar realisasi dari kepentingan golongan atau perseorangan tertentu semata-mata. Menurut Padmo Wahyono, dikemukakan bahwa apabila hukum hanya merupakan keseimbangan daripada kepentingan-kepentingan yang ada di masyarakat semata-mata, maka pasti yang lemah tidak terlindungi, tolok ukur inilah yang beliau maksudkan dengan fungsi hukum (Padmo Wahyono, $1992: 131$ ).

Dengan demikian hukum bukanlah sekedar alat dari mereka yang kuat, atau keseimbangan kepentingan-kepentingan yang ada di masyarakat, sekalipun terjadinya mungkin demikian. Dalam kaitannya dengan keadilan maka hukum harus memiliki fungsi tertentu. Sejalan dengan pemikiran tersebut Roscoe Pound telah melansir gagasan law as tools of social engineering, sebuah adagium yang telah membumi di kalangan para filsuf maupun praktisi hukum dan terutama mendapat pengaruh yang kuat di Indonesia, yang juga telah memprediksi kemungkinan terjadinya penyimpangan dari fungsi hukum ini. Idealnya adalah hukum dapat dipergunakan sebagai alat dalam membentuk masyarakat, tetapi berbeda halnya bilamana hal ini diterapkan dalam negara berkembang. Lazimnya, pada negara-negara berkembang adagium yang berkembang adalah law as tools of the ruler, sehingga dalam titik tertentu penyimpangan yang terjadi juga sangat luas. Dengan kata lain peraturan perundangundangan adalah alat bagi para penguasa dalam melanggengkan kepentingan-kepentingannya.

Jelas bahwa koneksitas antara hak asasi manusia dengan hukum telah terjabarkan, bahwa pemerintah melalui perangkat peraturan perundang-undangannya, harus menjamin perlindungan terhadap hak-hak asasi manusia, dimana hak asasi manusia dapat pula diterjemahkan sebagai hak tertinggi, atas masingmasing individu masyarakat yang diasumsikan setara dengan kedaulatan dari individu-individu yang bersangkutan. Sasarannya agar perangkat peraturan tersebut dapat memenuhi cita keadilan sebagai manifestasi dari kedaulatan rakyat. Keadilan merupakan sesuatu yang abstrak, berada dalam dunia sollen tumbuh secara filsafati dalam alam hayal manusia, namun tidak bisa diingkari bahwa semua orang mendambakan keadilan. Di dalam IImu hukum keadilan itu merupakan ide dan tujuan hukum namun secara pasti dan gramatikal keadilan itu tidak dapat didefinisikan oleh ilmu hukum, oleh karenanya keadilan harus dikaji dari sudut pandang teoritik dan filosofis. Atas dasar hal tersebut dalam tulisan yang singkat ini akan dibahas mengenai keadilan secara konseptual yang ditinjau dari sudut kajian filosofis yang pembahasannya difokuskan pada:

1. Konsep Keadilan Menurut Pemikiran Klasik

2. Konsep Keadilan Menurut Pemikiran Zaman Modern

3. Konsep Kadilan Sebagai Ide Hukum

\section{B. Konsep Keadilan Menurut Pemikiran Zaman Klasik}

Teori-teori yang mengkaji masalah keadilan secara mendalam telah dilakukan sejak jaman Yunani kuno. Konsep keadilan pada masa itu, berasal dari pemikiran tentang sikap atau perilaku manusia terhadap sesamanya dan terhadap alam lingkungannya, pemikiran tersebut dilakukan 
oleh kalangan filosof. Inti dari berbagai pemikiran filsafat itu terdiri dari berbagai obyek yang dapat dibagi kedalam dua golongan. Pertama obyek materia yaitu segala sesuatu yang ada atau yang mungkin ada, yakni kesemestaan, baik yang konkrit alamiah maupun yang abstrak non material seperti jiwa atau rohani termasuk juga nilai-nilai yang abstrak seperti nilai kebenaran, nilai keadilan, hakekat demokrasi dan lain sebagainya. Kedua obyek forma yaitu sudut pandang atau tujuan dari pemikiran dan penyelidikan atas obyek materia, yakni mengerti sedalam-dalamnya, menemukan kebenaran atau hakekat dari sesuatu yang diselidiki sebagai obyek material (Poejawijatna dalam Muhammad Nursyam, 1998 : 45).

Salah satu diantara teori keadilan yang dimaksud antara lain teori keadilan dari Plato yang menekankan pada harmoni atau keselarasan. Plato mendefinisikan keadilan sebagai "the supreme virtue of the good state", sedang orang yang adil adalah "the self diciplined man whose passions are controlled by reasson". Bagi Plato keadilan tidak dihubungkan secara langsung dengan hukum. Baginya keadilan dan tata hukum merupakan substansi umum dari suatu masyarakat yang membuat dan menjaga kesatuannya.

Dalam konsep Plato tentang keadilan dikenal adanya keadilan individual dan keadilan dalam negara. Untuk menemukan pengertian yang benar mengenai keadilan individual, terlebih dahulu harus ditemukan sifat-sifat dasar dari keadilan itu dalam negara, untuk itu Plato mengatakan: "let us enquire first what it is the cities, then we will examine it in the single man, looking for the likeness of the larger in the shape of the smaller"(The Liang Gie, 1982 : 22). Walaupun Plato mengatakan demikian, bukan berarti bahwa keadilan individual identik dengan keadilan dalam negara. Hanya saja Plato melihat bahwa keadilan timbul karena penyesuaian yang memberi tempat yang selaras kepada bagian-bagian yang membentuk suatu masyarakat. Keadilan terwujud dalam suatu masyarakat bilamana setiap anggota melakukan secara baik menurut kemampuannya fungsi yang sesuai atau yang selaras baginya.

Fungsi dari penguasa ialah membagi bagikan fungsi-fungsi dalam negara kepada masingmasing orang sesuai dengan asas keserasian. Pembagian kerja sesuai dengan bakat, bidang keahlian dan keterampilan setiap orang itulah yang disebut dengan keadilan. Konsepsi keadilan Plato yang demikian ini dirumuskan dalam ungkapan "giving each man his due" yaitu memberikan kepada setiap orang apa yang menjadi haknya. Untuk itu hukum perlu ditegakkan dan Undangundang perlu dibuat. Dalam kaitannya dengan hukum, obyek materianya adalah masalah nilai keadilan sebagai inti dari asas perlindungan hukum, sedangkan obyek formanya adalah sudut pandang normatif yuridis dengan maksud menemukan prinsip dasar yang dapat diterapkan untuk menyelesaikan masalah yang timbul di bidang penggunaan nilai keadilan dimaksud. Tentang nilai keadilan yang dimaksud terutama yang berkenaan dengan obyeknya yaitu hak yang harus diberikan kepada warga masyarakat. Biasanya hak ini dinilai dan diperlakukan dari berbagai aspek pertimbangan politik dan budaya, namun intinya tetap tidak berubah yaitu suum cuique tribuere.

Dari ungkapan di atas, terlihat dengan jelas Plato memandang suatu masalah yang memerlukan pengaturan dengan undang-undang harus mencerminkan rasa keadilan, sebab bagi Plato hukum dan undang-undang bukanlah semata-mata untuk memelihara ketertiban dan menjaga stabilitas negara, melainkan yang paling pokok dari undang-undang adalah untuk membimbing masyarakat mencapai keutamaan, sehingga layak menjadi warga negara dari negara yang ideal. Hukum dan undang-undang bersangkut paut erat dengan kehidupan moral dari setiap warga masyarakat.

Pembahasan yang lebih rinci mengenai konsep keadilan dikemukakan oleh Aristoteles. Jika Plato menekankan teorinya pada keharmonisan atau keselarasan, Aristoteles menekankan teorinya pada perimbangan atau proporsi. Menurutnya di dalam negara segala sesuatunya harus diarahkan pada cita-cita yang mulia yaitu kebaikan dan kebaikan itu harus terlihat lewat keadilan dan kebenaran. Penekanan perimbangan atau proporsi pada teori keadilan Aristoteles, dapat dilihat dari apa yang dilakukannya bahwa kesamaan hak itu haruslah sama diantara orang-orang yang sama (J.H. Rapar, 1991 : 82). Maksudnya pada satu sisi memang benar bila dikatakan bahwa keadilan berarti juga kesamaan hak, namun pada sisi lain harus dipahami pula bahwa keadilan juga berarti ketidaksamaan hak. Teori keadilan Aristoteles berdasar pada prinsip persamaan. Dalam versi modern teori itu dirumuskan dengan ungkapan bahwa keadilan terlaksana bila hal-hal yang sama diperlukan secara sama dan hal-hal yang tidak sama diperlakukan secara tidak sama.

Aristoteles membedakan keadilan menjadi keadilan distributif dan keadilan komutatif. Keadilan distributif adalah keadilan yang menuntut bahwa setiap orang mendapat apa yang menjadi haknya, jadi sifatnya proporsional. Di sini yang dinilai adil adalah apabila setiap orang mendapatkan apa yang menjadi haknya secara proporsional. 
Keadilan distributif berkenaan dengan penentuan hak dan pembagian hak yang adil dalam hubungan antara masyarakat dengan negara, dalam arti apa yang seharusnya diberikan oleh negara kepada warganya. Hak yang diberikan dapat berupa benda yang tak bisa dibagi (undivided goods) yakni kemanfaatan bersama misalnya perlindungan, fasilitas publik baik yang bersifat administratif maupun fisik dan berbagai hak lain, di mana warga negara atau warga masyarakat dapat menikmati tanpa harus menggangu hak orang lain dalam proses penikmatan tersebut. Selain itu juga benda yang habis dibagi (divided goods) yaitu hak-hak atau benda-benda yang dapat ditentukan dan dapat diberikan demi pemenuhan kebutuhan individu pada warga dan keluarganya, sepanjang negara mampu untuk memberikan apa yang dibutuhkan para warganya secara adil, atau dengan kata lain dimana terdapat keadilan distributif, maka keadaan tersebut akan mendekati dengan apa yang disebut keadaan dimana tercapainya keadilan sosial bagi masyarakat.

Sebaliknya keadilan komutatif menyangkut mengenai masalah penentuan hak yang adil di antara beberapa manusia pribadi yang setara, baik diantara manusia pribadi fisik maupun antara pribadi non fisik. Dalam hubungan ini suatu perserikatan atau perkumpulan lain sepanjang tidak dalam arti hubungan antara lembaga tersebut dengan para anggotanya, akan tetapi hubungan antara perserikatan dengan perserikatan atau hubungan antara perserikatan dengan manusia fisik lainnya, maka penentuan hak yang adil dalam hubungan ini masuk dalam pengertian keadilan komutatif. obyek dari hak pihak lain dalam keadilan komutatif adalah apa yang menjadi hak milik seseorang dari awalnya dan harus kembali kepadanya dalam proses keadilan komutatif. obyek hak milik ini bermacam-macam mulai dari kepentingan fisik dan moral, hubungan dan kualitas dari berbagai hal, baik yang bersifat kekeluargaan maupun yang bersifat ekonomis, hasil kerja fisik dan intelektual, sampai kepada hal-hal yang semula belum dipunyai atau dimiliki akan tetapi kemudian diperoleh melalui caracara yang sah. Ini semua memberikan kewajiban kepada pihak lain untuk menghormatinya dan pemberian sanksi berupa ganti rugi bila hak tersebut dikurangi, dirusak atau dibuat tidak berfungsi sebagaimana mestinya.

Di dalam konsep keadilan distributif muncul pertanyaan atau masalah tentang kapan timbulnya hak tersebut dan bagaimana pembagian hak itu, apa harus merata atau harus proporsional?. Berbeda dengan keadilan komutatif yang timbul dari hak yang semula ada pada seseorang atau yang diperolehnya secara sah dalam proses keadilan komutatif, maka dalam keadilan distributif dasarnya atau perolehan hak tersebut sematamata timbul dari keadaan di mana seseorang itu menjadi anggota atau warga dari suatu negara. Tidak seharusnya mereka yang bukan warga negara memperoleh kemanfaatan kecuali dalam hubungan yang bersifat timbal balik terutama dalam hubungan internasional antar negaranegara modern, sehingga seseorang asing dapat pula menikmati hak-hak atau fasilitas lain dari suatu negara yang dikunjunginya.

Mengenai persamaan ini, berkembang suatu pengertian bahwa persamaan bukan hanya menyangkut dengan seberapa jauh konstribusi warga negara terhadap negara atau sifat dari kontribusi tersebut, akan tetapi juga telah berkembang konsep persamaan dalam hal kemampuan, atau besar kecilnya halangan yang dialami oleh warga negara dalam memberikan konstribusinya. orang-orang yang tidak mempunyai modal, tidak berpendidikan, cacat tubuh dan sebagainya yang tetap menjadi warga negara harus mendapat jaminan dalam keadilan distributif untuk memperoleh bagian, minimal dapat memberikan kesejahteraan hidup baginya dan keluarganya. Hal ini merupakan bagian dari prinsip hak asasi manusia yang telah memperoleh pengakuan internasional. Dalam hal yang demikian tentu saja konsep persamaan itu diartikan dalam bentuk yang proporsional, karena tidak mungkin diberikan hak-hak yang secara aritmatik sama mengingat kontribusinya berbeda. Keadilan komutatif bertujuan untuk memelihara ketertiban masyarakat dan kesejahteraan umum, sebab disini dituntut adanya kesamaan dan yang dinilai adil ialah apabila setiap orang dinilai sama oleh karena itu sifatnya mutlak.

Dari konstruksi konsep keadilan Aristoteles tersebut, dapat ditarik benang merah bahwa keadilan distributif merupakan tugas dari pemerintah kepada warganya untuk menentukan apa yang dapat dituntut oleh warga negara dalam negaranya. Konstruksi keadilan yang demikian ini membebankan kewajiban bagi pembentuk Undang-undang untuk memperhatikannya dalam merumuskan konsep keadilan kedalam suatu Undang-undang.

Secara teoritis konsep keadilan Plato berdasar pada aliran filsafat idealisme, sedangkan konsep keadilan Aristoteles bertolak dari aliran filsafat realisme. Filsafat Plato mendasarkan diri pada alam ide yang bersifat mutlak dan abadi. Landasan filsafatnya ialah percaya dan menerima sepenuhnya alam nyata sebagai obyektifitas. Dalam pandangan filsafat ini alam 
nyata diterima sepenuhnya sebagai suatu totalitas yang menjadi sumber dari segala apa yang ada (J.H Rapar, 1993 : 92). Alam nyata tersusun dan bertalian secara hirarkis serta membentuk suatu totalitas yang di dalamnya makna dan ketertiban dapat dicapai manusia melalui akal pikirannya. Akal merupakan alat untuk mengetahui dan pengetahuan tersebut memberikan normanorma mengenai baik buruk yang berguna untuk manusia, seperti dikatakan oleh Plato keadilan ialah susunan ketertiban dari orang-orang yang menguasai diri sendiri (J.H. Rapar, 1993 : 102). Sebaliknya Aristoteles menekankan filsafatnya pada kesadaran, maksudnya dalam pandangan Aristoteles titik sentralnya adalah kesadaran yang ada pada subyek yang berpikir.

Gagasan Plato tentang keadilan ditransformasikan oleh Agustinus menjadi suatu konsepsi yang religius. Bagi Agustinus hakekat keadilan ialah adanya relasi yang tepat dan benar antara manusia dengan Tuhan, oleh sebab itu keadilan adalah suatu yang paling hakiki dalam bernegara dan keadilan itu hanya dapat terlaksana dalam kerajaan llahi yang merupakan gudang dari keadilan. Tuhan adalah sumber keadilan yang sesungguhnya, oleh sebab itu apabila seseorang memiliki hubungan yang baik dan benar dengan Tuhan maka ia akan dipenuhi oleh kebenaran dan keadilan.

Konsep keadilan yang bersifat religius dari Agustinus kemudian diperluas oleh Thomas Aquinas. Jika dalam konsepsi Agustinus keadilan hanya diperoleh dalam kerajaan Ilalhi yang perwujudannya di muka bumi dijalankan oleh Gereja, maka Thomas Aquinas mengakui adanya persekutuan lain di samping gereja yang bertugas memajukan keadilan yakni negara. oleh karena itu Thomas Aquinas membedakan keadilan kepada keadilan Ilahi dan keadilan manusiawi, namun tidak boleh ada pertentangan antara kekuasaan gereja dan kekuasaan duniawi. Dengan demikian konsep keadilan yang ditetapkan oleh ajaran agama, sepenuhnya sesuai dengan suara akal manusia sebagaimana terdapat dalam hukum alam. Sahnya hukum selalu digantungkan pada kesesuaiannya dengan hukum atau keadilan alamiah. Definisi yang diberikan pada keadilan berbunyi "justitia est contstans et perpetua voluntas jus suum cuique tribuendi" (keadilan adalah kecenderungan yang tetap dan kekal untuk memberikan kepada setiap orang apa yang menjadi haknya). Konsep justitia ini kemudian dianggap sebagai sifat pembawaan atau sudah dengan sendirinya melekat pada setiap hukum.

\section{Pemikiran Konsep Keadilan pada Zaman Modern}

Konsep keadilan pada jaman modern diwarnai dengan berkembangnya pemikiran-pemikiran tentang kebebasan, antara lain munculnya aliran liberalisme yaitu suatu aliran yang tumbuh di dunia barat pada awal abab ke-XVII Masehi. Aliran ini mendasarkan diri pada nilai-nilai dalam ajaran etika dari mazhab Stoa khususnya individualisme, sanksi moral dan penggunaan akal. Dalam bidang politik dianut konsepsi tentang pemerintahan demokrasi yang dapat menjamin tercapainya kebebasan. Tradisi liberalisme sangat menekankan kemerdekaan individu. Istilah liberalisme erat kaitannya dengan kebebasan, titik tolak pada kebebasan merupakan garis utama dalam semua pemikiran liberal (Lyman Tower Sargent, $1987: 63$ ).

Dalam konteks kebebasan tersebut, di dalam konsepsi liberalisme terkandung cita toleransi dan kebebasan hati nurani. Bagi kaum liberalis keadilan adalah ketertiban dari kebebasan atau bahkan realisasi dari kebebasan itu sendiri. Teori keadilan kaum liberalis dibangun di atas dua keyakinan. Pertama, manusia menurut sifat dasarnya adalah makhluk moral. Kedua, ada aturan-aturan yang berdiri sendiri yang harus dipatuhi manusia untuk mewujudkan dirinya sebagai pelaku moral. Berdasarkan hal ini keadilan dipahami sebagai suatu ketertiban rasional yang di dalamnya hukum alamiah ditaati dan sifat dasar manusia diwujudkan.

Berbeda dengan kaum liberal, penganut utilitarianisme menolak digunakannya ide hukum alam dan suara akal dalam teori mereka. Konsep keadilan pada aliran ini didasarkan pada asas kemanfaatan dan kepentingan manusia. Keadilan mempunyai ciri sebagai suatu kebajikan yang sepenuhnya ditentukan oleh kemanfaatannya, yaitu kemampuannya menghasilkan kesenangan yang terbesar bagi orang banyak.

Teori ini dikritik oleh anti utilitarianisme yang dipelopori oleh Dworkin dan Nozick. Menurut mereka utilitarianisme yang memperioritaskan kesejahteraan mayoritas, menyebabkan minoritas atau individu-individu yang prefensinya tidak diwakili oleh mayoritas di dalam suatu negara akan dihiraukan dan sebagai akibatnya mereka dirugikan atau kehilangan hak-haknya (John Rawls, 1994 : 43). Bagi penentang utilitrian, keadilan menolak argumen yang menyatakan bahwa hilangnya kebebasan sebagian orang dapat dibenarkan atas asas manfaat yang lebih besar yang dinikmati oleh orang-orang lain. oleh karena itu dalam suatu masyarakat yang adil, 
kebebasan warganegara yang sederajat tetap tidak berubah, hak-hak yang dijamin oleh keadilan tidak tunduk pada tawar-menawar politik ataupun pada pertimbangan kepentingan sosial (John Rawls, 1994 : 48).

Kritik Nozick terhadap utilitarianisme adalah bahwa utilitarianisme mengorbankan kebebasan individu untuk kepentingan mayoritas, utilitarianesme tidak mempertimbangkan fakta bahwa kehidupan seorang individu adalah satu-satunya kehidupan yang ia miliki. Kritik ini didasarkan pada pandangan politik yang dianut Nozick yang menuntut suatu komitmen ontologis terhadap moralitas dan organisasi sosial tertentu yang disebutnya dengan negara minimalis. Menurutnya negara minimalis ini bukan hanya berdasarkan pada ajaran-ajaran moral tertentu, akan tetapi negara itu juga merupakan ajaran moral. oleh karena itu apabila memiliki negara yang fungsinya lebih luas dan tidak terbatas hanya sebagai penjaga malam, serta mengutamakan kepentingan mayoritas, berarti mencabut terlalu banyak kebebasan warga negara, hal itu bertentangan dengan moral dan keadilan.

Menurut Hampstead serangan Nozick terutama ditujukan kepada rumus bahwa negara diperlukan atau merupakan alat terbaik untuk melakukan keadilan distributif (Hampstead, 1985 : 421). Terhadap ini Nozick mengatakan bahwa bila tiap orang memegang atau mempertahankan haknya yang diperoleh dengan sah, maka secara total distribusi dari hak-hak itu juga adil. Dalam keadaan yang demikian sudah barang tentu tidak ada tempat bagi negara melakukan campur tangan, apalagi memberi rumusan-rumusan atau prinsip-prinsip yang harus dianut dalam distribusi hak diantara warga negara. Negara cukup berfungsi sebagai penjaga malam, penjaga terhadap usaha pencurian dan menjaga hal-hal lain yang berhubungan dengan tindakan untuk mempertahankan hak-hak warga negara.

Kelemahan teori Nozick yang kental dengan warna indivudualistik dan liberal ini terletak dalam penerapannya, yaitu sangat sulit untuk melakukan kontrol baik dalam mengontrol negara minimilis maupun dalam kegiatan masyarakat. Artinya bagaimana mengontrol para individu yang sekian banyak dalam suatu negara dan bagaimana mengontrol kegiatan para individu di dalam berbagai lapangan usaha. Ini semua tidak bisa diserahkan kepada kekuatan pasar dan kehendak para individu semata-mata. Teori Nozick tersebut juga kurang realistis karena memisahkan individu dari kondisi masyarakat masa kini dengan kondisi kapitalisme dan liberalisme yang sudah sangat berubah.
Dalam konteks pemikiran modern tentang keadilan dalam kamus Bahasa Indonesia istilah keadilan berasal darik kata adil, artinya tidak memihak, sepatutnya, tidak sewenang-wenang. Jadi keadilan diartikan sebagai sikap atau perbuatan yang adil. Di dalam literatur Inggris istilah keadilan disebut dengan "justice" kata dasarnya "jus". Perkataan "jus" berarti hukum atau hak. Dengan demikian salah satu pengertian dari "justice" adalah hukum. Dari makna keadilan sebagai hukum, kemudian berkembang arti dari kata "justice" sebagai "lawfullness" yaitu keabsahan menurut hukum. Pengertian lain yang melekat pada keadilan dalam makna yang lebih luas adalah "fairness" yang sepadan dengan kelayakan. ciri adil dalam arti layak atau pantas, dapat dilihat dari istilah-istilah yang digunakan dalam ilmu hukum. Misalnya "priciple of fair play" yang merupakan salah satu asas-asas umum pemerintahan yang baik, "fair wage" diartikan sebagai upah yang layak yang sering ditemui dalam istilah hukum ketenagakerjaan. Hal yang sama dikemukakan dalam konsep keadilan Aristoteles yang disebutnya dengan "fairness in human action", Keadilan adalah kelayakan dalam tindakan manusia.

Bertolak dari peristilahan di atas, di dalam literatur ilmu hukum konsep keadilan mempunyai banyak pengertian sesuai dengan teori-teori dan pengertian tentang keadilan yang dikemukakan para ahli. Telaah pustaka menunjukkan bahwa masalah keadilan sejak dahulu telah menjadi bahan kajian baik dikalangan ahli filsafat maupun dikalangan agamawan, politikus maupun para pemikir atau ahli hukum sendiri. Akan tetapi sampai saat ini apabila timbul pertanyaan definisi keadilan. Ukuran yang digunakan untuk menentukan sesuatu itu adil atau tidak Akan timbul berbagai jawaban dan jawaban itu biasanya tidak pernah atau jarang memuaskan sehingga terus menjadi perdebatan, dengan demikian dapat disimpulkan bahwa berbagai rumusan mengenai keadialn merupakan rumusan yang relatif. Persoalan ini pada akhirnya mendorong banyak kalangan untuk mengambil jalan pintas dengan menyerahkan perumusan keadilan kepada pembentuk undangundang yang akan merumuskannya berdasarkan pertimbangan mereka sendiri.

Dari sekian banyak pengertian dan teori-teori yang dikemukakan para ahli, pada umumnya menyangkut mengenai hak dan kebebasan, peluang dan kekuasaan pendapat dan kemakmuran. Berbagai definisi keadilan yang menunjuk pada hal di atas antara lain dapat dilihat dari pengertian keadilan sebagai: (The Encyclopedia Americana, 1972 : 263) 
1. "the constant and perpetual disposition to render every man his due";

2. "the end of civil society;

3. "the right to obtain a hearing and decision by a court which is free of prejudice and improper influence";

4. "all recognized equitable rights as well as technical legal right";

5. "the dictate of right according to the consent of mankind generally";

6. "conformity with the principle of integrity, rectitude and just dealing";

Pengertian yang sama dikemukakan oleh Rudolph Heimanson yang mendefinisikan keadilan sebagai: redressing a wrong, finding a balance between legitimate but conflicting interest" (Rudolf Heimanson, 1967 : 96). Definisi ini menggambarkan bahwa nilai keadilan melekat pada tujuan hukum. Ide keadilan dicerminkan oleh keputusan yang menentang dilakukannya hukuman yang kejam, melarang penghukuman untuk kedua kalinya terhadap kesalahan yang sama. Menolak diterapkannya peraturan hukum yang menjatuhkan pidana terhadap tindakan yang dilakukan sebelum ada peraturan yang mengaturnya, menolak pembentukan undangundang yang menghapus hak-hak dan harta benda seseorang. Teori lain yang menyatakan bahwa keadilan melekat pada tujuan hukum dikemukakan oleh Tourtoulon yang dengan tegas menyatakan "lex injusta non est lex" yaitu hukum yang tidak adil bukanlah hukum. sebaliknya ide keadilan itu menuntut pemberian kepada setiap orang hak perlindungan dan pembelaan diri (Radbruch dan Dabin, 1950 : 432; Paul Siegart, $1986: 22$ ).

Pada dasarnya makna dari suatu pengertian atau definisi keadilan berupaya memberi pemahaman untuk mengenal apa itu keadilan. Dari definisi tersebut akan diketahui ciri-ciri suatu gejala yang memberi identitas atau tanda tentang keadilan. Akan tetapi tugas untuk menjelaskan keadilan, sifat dasar dan asal mula keadilan, atau mengapa suatu gejala tertentu disebut keadilan bukan merupakan tugas definisi keadilan, melainkan hanya dapat diterangkan dengan bantuan teori keadilan.

\section{Prinsip Keadilan Sebagai Ide Hukum}

Dalam berbagai literatur hukum banyak teoriteori yang berbicara mengenai keadilan. Salah satu diantara teori keadilan itu adalah teori etis, menurut teori ini hukum semata-mata bertujuan keadilan. Isi hukum ditentukan oleh keyakinan yang etis tentang yang adil dan tidak adil (Van Apeldoorn, 1995 : 10). Hukum menurut teori ini bertujuan untuk merealisir atau mewujudkan keadilan. Pemikiran filsafat tentang keadilan ini, terutama yang dipandang dari sudut filsafat hukum, sesuai dengan sudut pandang teori tentang tiga lapisan ilmu hukum yang meliputi dogmatik hukum, teori hukum dan filsafat hukum, sangat bermanfaat juga pada akhirnya bagi praktek hukum. Melalui pemikiran yang mendasar tentang apa yang menjadi hak yang telah menjadi buah pemikiran, dari beberapa ahli filsafat mulai dari Aristoteles sampai pada ahli filsafat masa kini, dapat disediakan referensi bagi pengambil keputusan untuk mengarahkan dan menjalankan fungsi pengaturan dalam praktek hukum.

Masalah keadilan telah lama menjadi bahan kajian dan bahan pemikiran oleh para ahli filsafat, para politikus dan rohaniawan, namun demikian apabila orang bertanya tentang keadilan atau bertanya tentang apa itu keadilan, akan muncul berbagai jawaban dan jawaban ini jarang memuaskan hati orang yang terlibat maupun para pemikir yang tidak terlibat. Bebagai jawaban mungkin akan muncul yang menunjukkan bahwa sukar sekali diperoleh jawaban umum, apabila dikemukakan jawaban atau batasan tentang keadilan oleh suatu masyarakat maka akan terdapat semacam jawaban yang sangat beragam, sehingga dapat dikatakan bahwa berbagai rumusan tentang keadilan merupakan rumusan yang bersifat relatif. Kesulitan tersebut mendorong orang terutama kaum positivis untuk mengambil jalan pintas dengan menyerahkan perumusan keadilan pada pembentuk undang-undang yang akan merumuskannya pada pertimbangan sendiri.

Pemikiran keadilan dalam hubungannya dengan hukum sejak lama sudah dikemukakan oleh Aristoteles dan Thomas Aquinus dengan mengatakan sebagai berikut (Radbruch dan Dabin, 1950:432): Justice forms the substance of the law, but his heterogeneous substance is composed of three elements: an individual element: the suum cuiquire tribuere (individual justice): a social element: the changing fundation of prejudgments upon which civilization reposes at any given moment (social justice), and a political element, which is based upon the reason of the strongest, represented in the particular case by the state (justice of the state). Hal ini menunjukkan ada pengaruh timbal balik antara hukum dan keadilan, yaitu bahwa hukum diciptakan berdasarkan nilainilai atau kaidah-kaidah moral yang adil, yang sudah ada terlebih dahulu dan yang telah hidup dalam masyarakat, jadi tugas pembentuk undangundang hanya merumuskan apa yang sudah ada. 
Sedangkan dilain pihak terdapat kemungkinan bahwa perumusan hukum itu sendiri hanya bersifat memberikan interpretasi, atau memberikan norma baru termasuk norma keadilan. Tentang apa yang dimaksud dengan keadilan meliputi dua hal, yaitu yang menyangkut hakekat keadilan dan yang menyangkut dengan isi atau norma, untuk berbuat secara konkrit dalam keadaan tertentu.

Hakekat keadilan yang dimaksud di sini adalah penilaian terhadap suatu perlakuan atau tindakan dengan mengkajinya dari suatu norma. Jadi dalam hal ini ada dua pihak yang terlibat, yaitu pihak yang membuat adanya perlakuan atau tindakan dan pihak lain yang dikenai tindakan itu, dalam pembahasan ini, pihak-pihak yang dimaksud adalah pihak penguasa atau pemerintah, sebagai pihak yang mengatur kehidupan masyarakat melalui instrumen hukum, dan pihak masyarakat sebagai pihak yang tata cara bertindaknya dalam negara diatur oleh ketentuan hukum.

Prinsip keadilan dalam pembentukan hukum dan praktek hukum, memperoleh kedudukan dalam dokumen-dokumen resmi tentang hak asasi manusia. Bahkan jauh sebelum dokumendokumen hak asasi itu dikeluarkan, prinsip keadilan telah dijadikan sebagai landasan moral untuk menata kehidupan masyarakat. Filsuf hukum alam seperti Agustinus mengajarkan bahwa hukum abadi yang terletak dalam budi Tuhan ditemukan juga dalam jiwa manusia. Partisipasi hukum abadi itu tampak dalam rasa keadilan, yaitu suatu sikap jiwa untuk memberi kepada setiap orang apa yang menjadi haknya. Prinsip tersebut mengindikasikan, inti tuntutan keadilan adalah bahwa untuk tujuan apapun, hak asasi seseorang tidak boleh dilanggar, hak asasi manusia harus dihormati, hak ini melekat pada manusia bukan karena diberikan oleh negara, melainkan karena martabatnya sebagai manusia. Hal ini berarti jika seseorang mempunyai hak atas sesuatu, orang lain juga mempunyai hak yang sama.

Pemahaman terhadap hal tersebut di atas, menunjukkan bahwa dalam kehidupan bermasyarakat dan bernegara, apa yang menjadi kepentingan bersama, akan mudah dicapai apabila masyarakat ditata menurut cita-cita keadilan. Keadilan menuntut agar semua orang diperlakukan sama, jadi keadilan merupakan suatu nilai yang mewujudkan keseimbangan antara bagian-bagian dalam masyarakat, antara tujuan pribadi dan tujuan bersama. Hal ini menunjukkan bahwa salah satu wujud cita-cita hukum yang bersifat universal adalah tuntutan keadilan. Menentukan apakah hukum itu adil atau tidak, tidak tergantung atau tidak diukur dari kriteria obyektif keadilan, melainkan diukur dari apa yang oleh masyarakat dianggap adil. Untuk memahami hukum yang mencerminkan rasa keadilan masyarakat, terlebih dahulu harus dipahami makna hukum yang sesungguhnya. Menurut pandangan yang dianut dalam literatur ilmu hukum, makna hukum itu ialah mewujudkan keadilan dalam kehidupan manusia. Makna ini akan tercapai dengan dimasukkannya prinsipprinsip keadilan dalam peraturan hidup bersama tersebut. Hukum yang dimaksud di sini adalah hukum positif yang merupakan realisasi dari prinsip-prinsip keadilan.

Bertolak dari pemikiran yang demikian, pengaturan hak dan kebebasan masyarakat dengan menggunakan kriteria keadilan, menunjukkan bahwa di dalam diri manusia, ada perasaan keadilan yang membawa orang pada suatu penilaian terhadap faktor-foktor yang berperan dalam pembentukan hukum. Keinsyafan akan perasaan keadilan ini bukan hanya dimiliki oleh warga negara tapi juga oleh penguasa, maka dengan dibangun di atas prinsip-prinsip keadilan, maka keadilan itu dapat disebut sebagai prinsip hukum atau ide hukum. Hal ini sesuai dengan ajaran Immanuel Kant yang mengatakan bahwa keadilan itu bertitik tolak dari martabat manusia. Dengan demikian pembentukan hukum harus mencerminkan rasa keadilan dan bertujuan untuk melindungi martabat manusia. Keadilan merupakan prisip normatif fundamental bagi negara (Franz Magnis Suseno, 1988:334). Atas dasar hal tersebut, kriteria prinsip keadilan, merupakan hal yang mendasar dan bersifat fundamental, sebab semua negara di dunia ini selalu berusaha menerapkan prisip-prinsip keadilan dalam pembentukan hukumnya. Prinsip keadilan mendapat tempat yang istimewa dalam seluruh sejarah filsafat hukum. Dalam konsep negara-negara modern penekanan terhadap prinsip keadilan diberikan dengan menyatakan bahwa tujuan hukum yang sebenarnya adalah untuk menciptakan keadilan dalam masyarakat.

Beberapa teori tentang keadilan seperti yang dikemukakan oleh Stammler, Radbruch dan Kelsen menitikberatkan keadilan sebagai tujuan hukum. Dengan demikian dapat disimpulkan bahwa hukum yang mewujudkan keadilan itu mutlak diperlukan dalam kehidupan berbangsa dan bernegara, tanpa adanya hukum hidup manusia menjadi tidak teratur dan manusia kehilangan kemungkinan untuk berkembang secara manusiawi.

Teori lain yang berbicara tentang keadilan adalah teori yang dikemukakan oleh John Rawls (John Rawls, 1971:310). Dalam teorinya 
dikemukakan bahwa ada tiga hal yang merupakan solusi bagi problema keadilan. Pertama prinsip kebebasan yang sama bagi setiap orang (principle of greatest equal liberty), tentang hal ini dirumuskan oleh John Rawls sebagai berikut: Each person is to have an equal right to the most extensive basic liberty compatible with a semilar liberty of thers. Rumusan ini mengacu pada rumusan Aristoteles tentang kesamaan, oleh karenanya juga kesamaan dalam memperoleh hak dan penggunaannya berdasarkan hukum alam. Rumusan ini inhern dengan pengertian equal yakni sama atau sederajat diantara sesama manusia. Usaha memperbandingkan ini juga secara tidak langsung merupakan pengakuan atau konfirmasi bahwa manusia selalu hidup bersama yang menurut Aristoteles disebut sebagai makhluk sosial, sehingga penentuan hak atau keadilan yang diterapkan adalah keadilan yang memperhatikan lingkungan sosial atau dengan kata lain harus merupakan keadilan sosial.

Prinsip ini mencakup kebebasan berperanserta dalam kehidupan politik, kebebasan berserikat dan berbicara termasuk kebebasan pers dan kebebasan beragama. Kedua prinsip perbedaan (the difference principle), yang dirumuskannya sebagai berikut: Social and economic inequalities are to be arranged so that they are bot (a) reasonably expected to be to everyone's advantage, and (b) attached to positions and office open to all (John Rawls, 1971:303). Rumusan ini merupakan modifikasi atau imbangan terhadap rumusan pertama yang menghendaki persamaan terhadap semua orang, modifikasi ini berlaku apabila memberi manfaat kepada setiap orang. Selain itu rumusan ini juga nampak ditujukan untuk masyarakat modern yang sudah memiliki tatanan yang lengkap, meskipun maksudnya adalah untuk memberi pemerataan dalam kesempatan kerja atau memberi peranan yang sama dan merata, akan tetapi bagaimana pun juga sudah terlihat perhatiannya yang sungguh-sungguh, untuk tidak melupakan dan meninggalkan orang lain yang sulit untuk memperoleh kedudukan dan kesempatan dalam kegiatan ekonomi. Jadi perbedaan sosial ekonomi, harus diatur agar memberi manfaat bagi warga yang kurang beruntung. Ketiga prinsip persamaan yang adil untuk memperoleh kesempatan bagi setiap orang (the principle of fair equality of opportunity), yaitu ketidaksamaan ekonomi harus diatur sedemikian rupa agar memberi kesempatan bagi setiap orang untuk menikmatiknya.

Prisip persamaan ini lebih lanjut dikemukakan oleh W. Friedmann sebagai berikut: "In a formal and general sense equality, is a postulate of justice. Aristoteles "distributive justive" demands the equal treatment of those equal before the law. This like any general formula of justice is however, applicable to any form of government or society; for it leaves it to a particular legal order to determine who are equal berfore the law... Equality in rights, as postulated by the extention of individual rights, ini principle, to all citizens distinct from a priveleged minoritiy"(W. Friedmann, 1971:385) Pada pokoknya pandangan yang dikemukakan Friedman tersebut mengandung dua pengertian.

Pertama, persamaan dipandang sebagai unsur keadilan, di dalamnya terkandung nilai-nilai universal dan keadilan tersebut pada satu sisi dapat diartikan sama dengan hukum, hal ini dapat dilihat dari istilah "justice" yang berarti hukum, akan tetapi pada sisi lain, keadilan juga merupakan tujuan hukum. Dalam mencapai tujuan tersebut, keadilan dipandang sebagai sikap tidak memihak (impartiality). Sikap inilah yang mengandung gagasan mengenai persamaan (equality) yaitu persamaan perlakukan yang adil terhadap semua orang.

Kedua, persamaan merupakan hak, persamaan sebagai hak dapat dilihat dari ketentuan The Universal Declaration Human Rights 1948, maupun dalam International Covenant on Economic, Socialo and Cultural Rights 1966 dan International Covenant on Civil and Political Rights 1966. Di dalam ketiga dokumen hak asasi manusia tersebut, dimuat ketentuan yang diawali dengan kata-kata: setiap orang ... dst. Demikian pula halnya di dalam Pasal 27 UUD 1945. Pasal ini pada dasarnya menempatkan persamaan dan kebebasan yang meliputi kepentingan dan tujuan dari hak itu ditetapkan dalam suatu hubungan. Mengenai hubungan persamaan dengan kebebasan ini, Friedmann pada pokoknya memandang bahwa kebebasan merupakan suatu alat yang membuka jalan seluas-luasnya bagi pengembangan personalitas, sedang persamaan dimaksudkan untuk memberi kesempatan yang sama terhadap setiap orang dalam mengembangkan personalitasnya.

Dalam kaitannya dengan pengaturan hak asasi dan kebebasan warga, teori ini merupakan teori yang cukup relevan untuk diterapkan, oleh karena itu, pembentukan hukum melaui undangundang yang bersifat membatasi kebebasan warga perlu mempertimbangkan teori ini, agar pengaturan melalui undang-undang tersebut mencerminkan rasa keadilan bagi warga.

Bagi bangsa Indonesia, kaitan teori itu dengan keadilan sosial yang berdasarkan Pancasila adalah bahwa konsepsi dan persepsi keadilan itu harus sesuai dengan perasaan suatu bangsa. 
Sejalan dengan itu apabila kita berbicara tentang hukum, berarti kita juga berbicara tentang keadilan. Hukum adalah suatu yang mengikat dan bila ikatan itu dikaitkan dengan manusia maka ikatan itu harus mencerminkan rasa keadilan. Keadilan sebagai konsepsi adalah keadilan dalam dunia "Sollen", namun demikian dunia Sollen dari keadilan itu patut dirumuskan dalam rangka usaha untuk menterjemahkan dunia ide itu menjadi dunia "Sein" atau kenyataan. oleh karena itu pengaturan hak dan kebebasan warga harus dibangun di atas prinsip-prinsip keadilan yang berdasarkan Pancasila. Untuk itu hukum yang dikehendaki adalah hukum yang sifatnya memberi perlindungan terhadap warga masyarakat, termasuk perlindungan terhadap hak warga untuk berserikat dan berkumpul. Perlindungan dalam hal ini, berarti bahwa rasa keadilan yang ada pada nurani warga harus terpenuhi.

Menggarisbawahi prinsip Indonesia adalah negara yang berdasarkan atas hukum, UUD 1945 sebagai hukum dasar menempatkan hukum pada posisi yang menentukan dalam sistem ketatanegaraan Indonesia. Dalam kaitan itu, konsep kenegaraan Indonesia antara lain menentukan bahwa pemerintah menganut paham konstitusional, yaitu suatu pemerintahan yang dibatasi oleh ketentuan yang temuat dalam konstitusi. Pada negara yang bersistem konstitusi atau berdasarkan hukum dasar, terdapat hirarki perundangan, dimana UUD berada di puncak piramida sedangkan ketentuan yang lain berada di bawah konstitusi. Konstitusi yang demikian ini dikenal dengan "stufenbau theory" Hans Kelsen.

Hans Kelsen mengemukakan tentang tertib hukum ini dalam proses pembentukan hukum yang bersifat hirarkis dan dinamis. Tertib hukum itu menurut Hans Kelsen disebut sebagai : The legal order is a system of norm. The question then arises: what is it that makes a system out of multitudes of norm? This question in close connection with the question as to the reason of validity of a norm (Hans Kelsen, 1961 : 110). Dia memandang tertib hukum itu sebagai suatu "stufenbau" dari beberapa tangga pembentukan hukum. Adanya pembentukan hukum oleh tingkat yang lebih rendah, yaitu pembentukan hukum yang kepadanya telah didelegasikan wewenang untuk itu, menurut pandangan Kelsen bergantung pada adanya suatu pembentukan hukum yang lebih tinggi, yaitu pembentukan hukum oleh yang mendelegasikan. Pada akhirnya mengenai berlakunya keseluruhan tertib hukum itu dapat dikembalikan pada suatu yang berakar dalam suatu "grundnorm". Tentang hal ini Kelsen menyebutkan: A norm the validity of which cannot be derived from a superior norm we call a "basic" norm. all norms whose validity may be traced to one and the same basic norm a system of norms, or an order (Hans Kelsen, 1961 : 112). Melalui "grundnorm" ini terjadi kesatuan di dalam proses pembentukan hukum yang dinamis dan di dalam tertib hukum yang memang ditimbulkan oleh "grundnorm" itu. Hal ini berarti bahwa "grundnorm" merupakan suatu norma yang tidak dapat dideduksikan lagi dari sumber lainnya. Artinya, "grundnorm" merupakan norma dasar yang keberadaan dan keabsahannya bukan merupakan bagian dari hukum positif, tetapi merupakan sumber dari hukum positif. Di sini terlihat bahwa pandangan Kelsen tentang "grundnorm" bukan merupakan sesuatu yang berbentuk tertulis akan tetapi merupakan: One may describe the Grundnorm as a constitution in the transcendental-logical sense, as distinct from the constitution in the positive legal sense. The latter is the contitution posited by human acts of will, the vailidity of which is based on the assumed (vorausgesertzte) basic norm (David Kayris, 1982:2210). Lebih jelas lagi jika diperhatikan bahwa apa yang disebutnya sebagai berikut: The basic norm is not created in a legal procedure by a law creating organ ... by a legal cat ... it is valid becouse it is presupposed to be valid: and it is presupposed to valid becouse without this presupposition no human act could be interpreted as a legal, especially as a norm creating, act (Hans Kelsen, 1961:114).

Indonesia juga mengenal tata urutan perundang-undangan menurut Stufenbau theory Hans Kelsen. Hal ini dapat dilihat dalam Tap MPRS No. XX/MPRS/1966 tentang memorandum DPRGR Mengenai Sumber Tertib Hukum RI dan Tata Urutan Perundang-undangan. Tap ini kemudian dicabut dengan Tap MPR No. III/MPR/2000 tentang Sumber Hukum dan Tata Urutan Peraturan perundang-undangan. Ketetapan MPR No.III/2000 ini, terdapat perbedaan dengan Tap MPRS No. XX/MPRS/1966 tentang sumber hukum dan tata urutannya. Jika pada Tap MPRS No. XX/1966 sumber tertib hukum itu dimana Pancasila merupakan sumber dari segala sumber hukum yang perwujudanya terdiri dari: Proklamasi 17 Agustus 1945, Dekrit Presiden 5 Juli 1959, UUD 1945 (Proklamasi) dan Supersemar 1966, maka di dalam Tap MPR No. III/MPR/2000 sumber hukum terdiri dari Pancasila dan UUD 1945. Begitu pula dengan tata urutan perundang-undangan terjadi perubahan, pada Tap MPRS No. XX/MPRS/1966 posisi Undang-undang terjadi perubahan, pada Tap MPRS No. XX/MPRS/1966 posisi Undangundang sederajat dengan Peraturan Pemerintah Pengganti Undang-undang (Perpu), sedangkan 
Tap MPR No. III/MPR/2000 Perpu berada di bawah Undang-undang, dan peraturan daerah merupakan salah satu urutan perundang-undangan yang semula pada Tap MPRS No.XX/MPRS/1966 hanya merupakan peraturan pelaksana. Selanjutnya mengenai tata urutan dan pembentukan peraturan perundang-undangan dimuat dalam UU No. 10 Tahun 2004 dan kemudian diganti dengan UU No. 12 Tahun 2011, ari beberapa ketentuan tersebut ada satu persamaan yaitu bahwa semua peraturan hukum yang berlaku tidak boleh bertentangan dengan ketentuan hukum yang lebih tinggi sesuai dengan tata urutan perundang-undangan.

Mengikuti pemikiran Hans Kelsen timbul pertanyaan tentang Grundnorm dari peraturan atau hukum Indonesia. Dalam banyak literatur, jelas dikemukakan bahwa Pancasila adalah Grundnorm atau norma dasar, yang merupakan sumber dari segala sumber hukum yang berlaku dan yang akan diberlakukan di Indonesia. Hal ini dapat dilihat dari pandangan yang mengatakan bahwa Pancasila berkedudukan sebagai landasan unsur konstitutif dan regulatif, sebagai Grundnorm sumbernya dari segala sumber hukum dan landasan filosofis dari bangunan hukum nasional, dan pelbagai manifestasi budaya Indonesia yang memancarkan dan menghadirkan "Geislichen Hintergrund" yang khas (Padmo Wahyono, 1983:214). Dengan demikian hukum tidak terlepas dari nilai yang berlaku di masyarakat, bahkan dapat dikatakan bahwa hukum itu merupakan pencerminan nilainilai yang berlaku dalam masyarakat. Hukum yang baik adalah hukum yang sesuai dengan yang hidup dalam masyarakat. Ini berarti bahwa hukum positif Indonesia bersumber pada nilai, yaitu nilai-nilai yang terkandung dalam Pancasila yang merupakan asas kerohanian negara Indonesia. Jika konsep Grundnorm menurut teori hukum murni Hans Kelsen, dihubungkan dengan Pancasila sebagai norma dasar dalam pembentukan hukum Indonesia. Sangat sulit untuk menempatkan atau bahkan tidak mungkin memposisikan teori hukum murni tersebut untuk menafsirkan Pancasila sebagai Grundnorm. Alasannya, dilihat dari sudut pandang teori hukum, apa yang dikemukakan oleh Hans Kelsen dengan teori hukum murni, secara tegas memisahkan hukum dengan moral. Hal ini dapat dilihat dari teori Kelsen yang mengtakan; suatu analisis tentang struktur hukum positif yang dilakukan seeksak mungkin, suatu analisis yang bebas dari semua pendapat etik atau politik mengenai nilai (c.K. Allen, 1964:52). Pancasila sebagai pandangan hidup, sebagai sumber dari segala sumber hukum atau sebagai asas kerohanian sarat dengan nilai moral. Oleh karena itu teori hukum murni tidak mungkin menjelaskan Pancasila sebagai Grundnorm.

Grundnorm merupakan sistem nilai, dalam esensinya sistem nilai itu dapat dibedakan menjadi nilai dasar dan nilai tujuan. Sebagai nilai dasar berarti merupakan sumber nilai bagi pembuat kebijakan dan juga sebagai pembatas dalam implementasinya, sebagai landasan dan acuan untuk mencapai atau memperjuangkan sesuatu. Sedang sebagai nilai tujuan berarti merupakan sesuatu yang harus dan layak untuk diperjuangkan. Sistem ini mempunyai peranan penting dalam hubungannya dengan pembentukan hukum, sistem nilai ini diejawantahkan ke dalam berbagai asas hukum dan kaidah hukum yang secara keseluruhan mewujudkan sebagai sistem hukum.

Pada sisi lain Pancasila sebagai pedoman hidup bangsa, di dalamnya terkandung sistem nilai yang kemudian berkelanjutan menjadi norma-norma kehidupan. Nilai diartikan oleh Mc cracken (Mc craken, 1950 : 25) sebagai: "volue is that aspect of a fact or experience in virture of which it is seen to contain in its nature or essence the sufficient reason for its existence as such a deteminate fact or experience, or the sufficient reason form its being regarded as an end for practice or contemplation". Senada dengan itu, Notonagoro mengatakan : ... Pancasila bukan hanya satu konsepsi politis, akan tetapi buah hasil perenungan jiwa yang dalam, buah hasil penyelidikan cipta yang teratur dan seksama di atas basis pengetahuan dan pengalaman yang luas (Notonagoro, 1979 : 31). Dengan demikian Pancasila dalam keseluruhan artinya adalah nilai-nilai kejiwaan bangsa, hasrat keinginan yang mendalam dari bangsa, ikatan antara jiwa bangsa dan kenyataan hidup.

Dalam kaitan ini Flew menyatakan; .... About what things in the world are good, desirable, and important (Antony Flew, 1984:465). Jadi nilai merupakan sesuatu yang berkaitan dengan yang dipandang baik, diperlukan dan penting bagi kehidupan. Dari rumusan tersebut dapat diketahui bahwa nilai memiliki karakteristik baik, bersahaja dan penting. Karakteristik lain tentang nilai dikemukakan oleh The Lie Anggie (The Liang Gie, 1982:127) sebagai berikut:

a. Dari perkataan nilai dapat dilihat dari sudut kata kerja (menilai) atau dilihat dari sudut kata sifat (bernilai), atau dilihat dari sudut kata benda (suatu nilai), dan sebagainya.

b. Nilai adalah merupakan dasar suatu perbuatan atau pilihan.

c. Nilai itu sendiri sering dikatakan merupakan suatu pilihan 
d. Pada situasi tertentu setiap orang dapat berselisih dalam mempertimbangkan suatu nilai.

e. Nilai dapat dibedakan ke dalam dua macam, yaitu nilai intrinsik dan nilai instrumental.

f. Nilai berkaitan dengan hal yang positif dan yang negatif, yaitu berkaitan dengan kebaikan dan kejahatan.

g. Penilaian kapan saja berkaitan dengan kehidupan.

Sedang Koesneo mengemukakan bahwa di dalam hidup manusia, nilai-nilai banyak ragam dan macamnya, ada nilai kebenaran, nilai kesusilaan, nilai keindahan dan ada nilai hukum (Moch Koesnoe, 1997:71). Sistem nilai ini secara teoritis dan konsepsional disusun sedemikian rupa, sehingga nilai-nilai dan norma-norma yang terkandung di dalamnya merupakan suatu jalinan pemikiran yang logis. Hal ini berarti bahwa nilainilai yang berkaitan dengan keadilan sosial akan menempati kedudukan yang penting di dalam hukum. Untuk itu dalam pengaturan hak dan kebebasan warga negara nilai-nilai keadilan harus mendapat perhatian. Berdasarkan hal yang demikian ini, terlihat dengan jelas bahwa Pancasila mengharuskan tertib hukum Indonesia sesuai dengan norma-norma moral, kesusilaan, etika dan sebagainya. Hal ini menunjukkan bahwa Pancasila selain mengandung nilai moral juga mengandung nilai politik.

Menururt Moh. Hatta sebagaimana dikutip Ruslan Saleh, Pancasila terdiri atas dua fundamen yaitu fundamen politik dan fundamen moral (Ruslan Saleh, 1979:45). Dengan meletakkan fundamen moral di atas, negara dan pemerintahannya memperoleh dasar yang kokoh, yang memerintahkan berbuat benar, melaksanakan keadilan, kebaikan dan kejujuran serta persaudaraan keluar dan ke dalam. Dengan fundamen politik pemerintahan yang berpegang pada moral yang tinggi diciptakan tercapainya suatu keadilan sosial bagi seluruh rakyat Indonesia. Mengacu pada pemikiran Moh. Hatta di atas, dapat disimpulkan bahwa Pancasila bukan hanya norma dasar dari kehidupan hukum nasional, akan tetapi juga merupakan norma dasar dari norma-norma lain, seperti norma moral, norma kesusilaan, norma etika dan nilai-nilai. oleh karena itu Pancasila mengharuskan agar tertib hukum serasi dengan norma moral, sesuai dengan norma kesusilaan dan norma etika yang merupakan pedoman bagi setiap warga negara untuk bertingkah laku.

Hukum adalah sesuatu yang abstrak, tidak dapat dilihat dan tidak dapat diraba, yang dapat dilihat adalah tingkah laku manusia seharihari, lebih tepat lagi tingkah laku hukum manusia. Hukum itu sendiri merupakan hasil karya manusia berupa norma yang berisikan petunjuk bagi manusia untuk bertingkah laku, hal ini berkaitan dengan keberadaan manusia sebagai makhluk yang berakal budi, sehingga setiap tingkah laku manusia harus diatur secara normatif dengan arti bahwa manusia harus bertingkah laku sesuai dengan norma-norma yang ditentukan sebagai pegangan hidupnya. Melalui penormaan tingkah laku ini, hukum memasuki semua aspek kehidupan manusia, seperti yang dikatakan Steven Vago; "The normative life of the state and its citizens". Agar supaya tingkah laku ini diwarnai oleh nilainilai Pancasila, maka norma hukum positif yang berlaku di Indonesia harus bernapaskan Pancasila (Steven Vago, $1981: 9$ ).

Formulasi yang demikian ini mengandung arti bahwa peraturan perundang-undangan, mengandung norma hukum yang di dalamnya terdapat patokan penilaian dan patokan tingkah laku. Patokan penilaian ini tidak hanya terbatas pada macam-macam nilai, akan tetapi merupakan satu kesatuan atau keterpaduan yang disebut dengan sistem penilaian. Melalui sistem penilaian ini, dapat dirumuskan petunjuk tingkah laku, tentang perbuatan apa saja yang mesti dilakukan dan yang harus ditinggalkan. Penilaian terhadap tingkah laku manusia bukan merupakan penilaian yang berdiri sendiri, melainkan merupakan bagian dari suatu ide yang lebih besar, yaitu ide tentang masyarakat yang dicita-citakan.

\section{E. Simpulan}

Dari uraian di atas terlihat bahwa konsepkonsep keadilan selalu didasarkan pada suatu aliran filsafat atau pemikiran tertentu sesuai dengan kondisi pemikiran manusia pada waktu itu. Dari definisi dan teori-teori tentang keadilan, dapat diketahui bahwa konsep keadilan mengandung banyak pengertian. Dari teori-teori dan pengertian keadilan itu, terdapat dua hal yang bersifat universal dari konsep keadilan yaitu tujuan dan karakter atau ciri-ciri keadilan. Tujuan adalah hal yang akan dicapai dalam hubungan hukum baik antara sesama warga, maupun antara warga dengan negara atau hubungan antar negara. Sedang ciri-ciri atau karakter yang melekat pada keadilan adalah: adil, bersifat hukum, sah menurut hukum, tidak memihak, sama hak, layak, wajar secara moral dan benar secara moral. Konsepkonsep keadilan bersumber dari alam pikiran barat pada zaman klasik dan zaman modern yang didasarkan pada pandangan dan pemikiran yang berkembang sesuai dengan jamannya. 
Keadilan dapat diartikan sebagai kebaikan, kebajikan dan kebenaran, yaitu suatu kewajiban moral yang mengikat antara anggota masyarakat yang satu dengan lainnya. Keadilan sebagai nilai yaitu yang menjadi tujuan yang disepakati bersama oleh anggota masyarakat serta diusahakan pencapaiannya demi keadilan itu sendiri. Makna lain dari keadilan adalah sebagai hasil atau suatu keputusan yang diperoleh dari penerapan atau pelaksanaan hukum. Keadilan juga diartikan sebagai unsur ideal, yaitu sebagai suatu cita atau suatu ide yang terdapat dalam semua hukum.

\section{daftar Pustaka}

Allen, c.K. 1964. Law in the Making. New York : oxford University Press.

Flew, Antony. 1984. A Dicionary of Philosophy. London : Pan Books.

Davidson, Scott. 1994. Hak Asasi Manusia. Jakarta : Grafiti Press.

Franz Magniz Suseno. 1988. Etika Politik. Jakarta : Gramedia.

Heimanson, Rudolf. 1967. Dictionary of Political Science and Law. Dobbs Fery: oceana Publication.

J.H. Rapar. 1991. Filsafat Politik Plato. Jakarta : Rajawali Press.

1993. Filsafat Politik Aristoteles. Jakarta : Rajawali Press.

Kayris, David. The Politics of Law, A Progressive Critique. New York : Pantheon Books.

Kelsen, Hans. 1961.General Theory of Law and State. University Press cambridge, Harvard

Lord Lloyd of Hampstead \& MDA Preeman. 1985. Introduction to Jurisprudence, EnglishLanguageBook Society. Steven, London, 1985

Mc cracken. 1950. Thinking and Voluing; An Introduction Portly Histrorical, to the Study of the Philosophy of Value. London : Mac Millan.

Moch. Koesneo. 1997. Pengantar Ke Arah Filsafat Hukum. Surabaya : Ubhara Press.

Mohammad Nursyam. 1998. "Penjabaran Filsafat Pancasila Dalam Filsafat Hukum. Sebagai Landasan Pembinaan Hukum Nasional”. Disertasi. Universitas Airlangga Surabaya

Padmo Wahyono. Indonesia Negara Berdasarkan Atas Hukum. Jakarta : Ghalia Indonesia.

Rajawali Press.

Radbruch \& Dabin. 1950. The Legal Philosophi. New York : Harvard University Press.

Rawls, John. 1971. A Theory of Justice, Massachussets : The Bellnap Press of Havard University Press.

Ruslan Saleh. 1979. Penjabaran Pancasila ke Dalam UUD 1945 Dalam Perundang-undangan. Jakarta : Aksara Baru.

Siegart, Paul. 1986. The Lawfull Right of Mankind an Introduction to the International LegalCode of Human Right. New York : oxford University Press.

The Liang Gie. 1982. Teori-teori Keadilan. Yogyakarta : Sumber Sukses.

The Encyclopedia Americana, Volume 16 Americana corporation, New York, 1972

Tower Sargent, Lyman. 1987. Ideologi-Ideologi Politik Kontemporer. Jakarta : Erlangga.

Vago, Steven. 1981. Law and Society. New Jersey : Prentice Hall, Inc.

Van Apeldoorn. 1995. Inleiding tot de Studie van het Nederlandse Recht, W.E.J. Tjeenk Willink. Zwolle.

W. Friedmann. 1971. The State and The Rule of Law in Mix Economy. London : Steven \& Son. 